\title{
Why is there a higher rate of self-employed people in the minority sectors than in the majority sector: Study case in Israel 2011
}

\author{
Tal Shahor
}

The Academic College of Emek Yezreel, Israel.

Email: tals@yvc.ac.il

\begin{abstract}
One of the main problems facing governments today is the integration of the minority sectors into the national economy. This study examines this issue in the context of the Arab minority and the Jewish majority in Israel. An important aspect of this problem is the integration of Arabs into the Israeli workforce. The objective of this study is to investigate this problem by dividing the workforce into two sectors - wage-earning employees and the self-employed. The basis for the discussion is that an employee in the job market who, for different reasons, is unable to receive suitable remuneration that is on a par with his or her skill level will turn to the self-employed sector. Within this framework, I compared the way in which the workforce in each sector (Jewish and Arab) was divided between the self-employed sector and the wage-earning employee sector and from this distribution I sought to learn about the integration of Arabs into the Israeli workforce. in 2011 the results of this study show that within the Arab population, the self-employed sector has a relative advantage because of the weakness of the wageearning employee sector.
\end{abstract}

Keywords: Salaried employee, self-employed, Jews Arabs, income disparity

\section{Introduction}

This study addresses a number of economically significant aspects of the relationship between the Jewish majority and the Arab minority in Israel. The relevance of this study is not limited solely to Israel as many countries throughout the world find themselves contending with ethnic minorities and the associated problems. This study looks at Israeli citizens living within the Green Line (Israel's pre-1967 border as defined by the United Nations).1 The majority of the population living within these borders is Jewish (80\%); however, there is also a sizeable Arab minority (the remaining $20 \%$ ) living within these borders too. Within the Israeli Arab segment of the population, the vast majority are Muslims, although approximately $10 \%$ of Israeli Arabs are Christians who, in many ways, differ from the Muslim segment (birth rate, standard of education, and so on).

In socio-economic terms, the Arab minority is in an inferior position, as can be seen by the lowly position of the Arab local authorities in the socio-economic clusters. These clusters are used to gauge the strength of the local authorities. The Central Bureau of Statistics (2008) uses certain criteria (family size, average income, standard of education, standard of accommodation, mobility level, and so on) to divide the local authorities in Israel into ten socio-economic clusters. The first cluster includes the weakest local authorities and the tenth cluster includes the strongest. These classifications are updated every few years. The following table shows the cluster breakdown of the local authorities based on sector for the year 2008.

Table 1. Breakdown of Local Authorities into Socio-Economic Clusters based on Sector for the Year 2008

\begin{tabular}{lll}
\hline Cluster & Arab Authorities & Jewish Authorities \\
\hline \hline 1 & 3 & 2 \\
\hline 2 & 37 & 3 \\
\hline 3 & 18 & 6 \\
\hline 4 & 6 & 13 \\
\hline 5 & 2 & 30
\end{tabular}

1 For those who need a reminder about Israel's borders - in 1948, when the State of Israel was established its borders followed what is known today as the Green Line. in 1967, Israel occupied additional territories (Gaza, the West Bank and the Golan Heights) but never annexed them, and in 1992 following the Oslo Accords, transferred most of those territories to the Palestinian Authority. The residents in these territories are not part of Israel's population and are therefore not included in this study. 


\begin{tabular}{lll}
\hline 6 & 0 & 14 \\
\hline 7 & 0 & 13 \\
\hline 8 & 0 & 23 \\
\hline 9 & 0 & 7 \\
\hline 10 & 0 & 3 \\
\hline \hline Total & 66 & 114 \\
\hline
\end{tabular}

We can see from the table that the majority of Arab local authorities are positioned in the four lowest clusters. One of the factors contributing to the low socio-economic position of Israeli Arabs which will be discussed in this study is the inferior status of the Arab sector in employment-related matters and particularly concerning work-generated income. Epstein, Gharrah and Cohen (2001), Hasson and Abu-Asbah (2004), and Hasson and Karayanni (2006) found that there was inequality in employment opportunities because of a dearth of job openings in Arab settlements and because of difficulties faced by Arabs wanting to integrate into the work place in Jewish settlements. Furthermore, it was found that despite the improved education of the Arab labor force, the Arabs are still unable to utilize their skills to the fullest in the Israeli labor market. Zussman and Friedman (2008) found that between the years 1987 - 2005 the disparity between the hourly rate paid to Arabs and Jews actually grew. There are several possible approaches that might explain income disparity between different groups of workers:

The Human Capital approach, presented by Becker (1964): This approach asserts that an employer operating in a competitive market and striving to increase profits as much as possible will pay the employee according to his or her marginal output. This method maintains that if the high-potential employee with human capital produces more than the employee without human capital, the former should earn a higher salary than the latter.

Professional Segregation approach (Haberfield, 1990): This approach focuses on qualities and skills required by the labor market (whereas the Human Capital approach focuses on the employee and his or her attributes). According to this approach, the salary paid is based on the job itself and not on the person doing it. There are some jobs and professions that are more important to the employer than others. With this approach, Jews will earn more than Arabs if they are doing a job that the employer pays a higher wage for.

Another possibility is that one sector of the population discriminates against the other (in this case, against the Arabs): According to the Human Capital approach, there is discrimination when the average wage earned by the Arabs is lower than that earned by the Jews despite the similar levels of human capital of the two sectors. According to the Professional Segregation approach discrimination exists when a lower wage is paid for the professions in which Arabs are working.

The outcome in all three situations above is the same - Arab Israelis encounter difficulties integrating into the Israeli workforce as salaried employees. These difficulties can be circumvented by becoming self-employed as the individual is not required to "show documents (qualifications)", and his or her income will depend on their ability to "provide the goods" for the customer. We can therefore assume that a greater number of people will be self-employed in the Arab sector, and that the disparity in salaries between Jews and Arabs in the self-employed sector will be less than the disparity in the salaried employee sector. The objective of the first section of this study is to test both of the above-mentioned assumptions. in the second section of the study, the income disparity between the two sectors (self-employed and salaried employees) will be reviewed to check if it stems from discrimination against the Arab minority.

\section{Data Description}

Data for this study (self-employed income and Muslim - Christian population division) will be taken from population records for the settlements. Arabs and Jews do not usually live in the same settlements, thus the division into sectors will be based on this data. The following settlements were removed from the sample: (1) mixed settlements (Jerusalem, Acre, MaalotTarshicha, Nazareth Illit and Ramleh); (2) settlements in which the Druze comprise more than $30 \%$ of the population because a large number of this ethnic group serve in the standing army and their data is not available through the Central Bureau of Statistics. in the end, the data base includes $53 \mathrm{Arab}$ and 87 Jewish settlements. Data about income and the division into self-employed / salaried employees is based on data supplied by the Central Bureau of Statistics (2014) for 2011. 


\section{Data Analysis}

As mentioned above, the objective of the first section of this paper is to test two questions: (1) Will the number of selfemployed in the Arab sector be greater than the number in the Jewish sector? (2) Will the income disparity between Jews and Arabs in the self-employed sector be smaller than the disparity in salaries in the salaried-employee sector?

These two questions were tested using the data in the following table. The first row of the table shows the rate of selfemployed in the overall workforce for both sectors. The second row shows self-employed income for each sector during the same years, and the third row shows the salaries for the salaried employees.

Table 2. Comparison of the percentage of self-employed and the average salary of self-employed and salaried-employees in the Jewish and Arab sectors (in current prices)

\begin{tabular}{llll}
\hline Sector & Arab & Jewish & Ratio between Arabs \& Jews \\
\hline \hline Percentage of self-employed & 0.078 & 0.067 & .117 \\
\hline Self-employed income & 7,000 & 9,205 & 0.76 \\
\hline Salaried-employee income & 5,018 & 8,491 & 0.59 \\
\hline
\end{tabular}

The above data shows that: (1) the number of self-employed in the Arab sector is greater; (2) the disparity in income between Jews and Arabs in the self-employed sector is lower than the income disparity in the salaried-employee sector. These findings indicate that Arabs have a relative advantage in the self-employed sector which seems to stem from their weakness in the Israeli labor market.

\section{Does the disparity in income between the Jews and Arabs stem from discrimination?}

The question that comes to mind is what makes it difficult for Arabs to integrate into the salaried-employee sector? Is it discrimination or are there other causes? Are the qualifications of the Arab sector (such as level of education) ill-suited to the Israeli labor market? It should be pointed out in this context that ethnic-based discrimination occurs when those belonging to a specific sector receive less because they belong to the said sector. Thus, the fact that there is a disparity between the two population sectors is not enough to indicate that discrimination occurs. for example, in the labor market ethnic-based discrimination exists if a worker from one specific ethnic group earns less than a worker from another ethnic group even though both workers have identical skills. and indeed, articles examining ethnic-based discrimination in the labor market were not satisfied with finding disparities in salary and professional prestige. Instead, they addressed the question of why ethnic origin is liable to cause such disparities (Becker (1993); Arrow (1972); Darity, (1989), and others). Cleiman (2001) makes a similar claim in his comments on an article by Gharrah and Cohen (2001). He claims data showing that there is more poverty in the Arab sector is insufficient proof of discrimination. in order to prove the existence of discrimination "a straightforward description of the characteristics of the poor Arab population in terms of its distribution according to age, family size, education, etc. in comparison to the poor Jewish population is needed. Only data such as this will help differentiate between the increased occurrence of poverty in the Arab sector stemming from demographic differences and that which stems from discrimination". Similar issues are also raised in a study by Dahan (1998) which examines inequality in general in the labor market in Israel, and in this context also refers to wages earned by the Arabs. for this purpose, he adds a dummy variable to the equation that determines salaries for the Arab sector in Israel. His findings show that there is a disparity between salaries in the Jewish sector and salaries in the Arab sector. However, he points out that this result does not provide enough information to reach the conclusion that this disparity is caused by racial or nationalist discrimination because the regression does not include all variables affecting salary levels.

One of the ways to examine this question is to divide the Arab sector into two groups: Muslims and Christians. The test is based on the assumption that the Jewish population (which forms the greater part of the labor market) does not differentiate between Christians and Muslims (refer to explanation in the appendix). Consequently, if the weak Arab position in the labor market is caused by ethnic discrimination we would not expect to see any difference between the Christian Arabs and the Muslim Arabs. 
We will run two models to test this assumption. in the first model, the dependent variable is the average income for a salaried position which will be noted by IW. The explanatory variables are: (1) the number of Muslims in every local authority and will be noted by M; (2) the number of Christians in every local authority will be noted by $\mathrm{C}$, and (3) proximity of local authority to the boundary of the Tel Aviv District, which is called "economic heart of the country". Israel has a clear coreperiphery structure, where the Tel Aviv District serves as the country's economic and business center located in its geographic center (close to the middle of the north-south axis). This variable will be noted by TLV. This produced the following model:

(1) $\mathrm{I}_{\mathrm{w}}=\beta_{0}+\beta_{\mathrm{c}} \mathrm{C}+\beta_{\mathrm{m}} \mathrm{M}+\beta_{\mathrm{t}} \mathrm{TLV}$

Table 3 shows the results of the first regression.

Table 3. Factors affecting salaried-employee income

\begin{tabular}{lll}
\hline Variable & Coefficients & P-value \\
\hline \hline Intercept & $9,655.44$ & 0.000 \\
\hline Christians & -9.39 & 0.46 \\
\hline Muslims & -33.66 & 0.000 \\
\hline TLV & -15.78 & 0.000 \\
\hline \hline Adjusted R Square & 0.41 & \\
\hline
\end{tabular}

We can learn two points from the table that are significant to our study:

The coefficient for Muslims is negative. This implies that when the number of Muslims increases the income from salaried positions decreases. This could indicate that income earned by Muslims is lower.

On the other hand, the Christian coefficient is not significant. This implies that the measure of Christians does not affect the income from a salaried position. This could indicate that the income earned by Christians is not lower than the income earned by the Jewish majority.

In the second model, the dependent variable is self-employed income noted by Iself. The explanatory variables are the same as for the first model. This produced the following model:

(2) $\mathrm{I}_{\text {self }}=\beta_{0}+\beta_{\mathrm{c}} \mathrm{C}+\beta_{\mathrm{m}} \mathrm{M}+\beta_{\mathrm{t}} \mathrm{TLV}$

Table 4 shows the results of this regression

Table 4. Factors affect self-employed income

\begin{tabular}{lll}
\hline Variable & Coefficients & P-value \\
\hline \hline
\end{tabular}




\begin{tabular}{lll}
\hline \hline Intercept & 9,294 & 0.000 \\
\hline Christians & -3.64 & 0.705 \\
\hline Muslims & -16.85 & 0.000 \\
\hline TLV & -9.13 & 0.002 \\
\hline \hline Adjusted R Square & 0.24 & \\
\hline
\end{tabular}

We can also see in this table that the Christian coefficient is not significant. This implies that self-employed income of Christians and Jews who live in the same area does not differ. Consequently, here we also reach the same conclusions as for the previous table. However, we can also reach another important conclusion. The self-employed income of the Muslims is lower by approximately 16, while the income of the salaried-employees (as can be seen in table 3) is lower by 33.66. This reinforces the result that we received previously, which indicated that the disparity between Jews and Arabs in the self-employed sector is smaller, in other words, Arabs find it easier to function as self-employed.

\section{Conclusion}

The above discussion generates a number of conclusions: (1) the weaker group in terms of income is the Muslim Arab population. The Government must therefore take steps to improve their situation; (2) this weak position is not typical of the Christian population. If we accept the claim that the Jewish population does not differentiate between Christian Arabs and Muslim Arabs, then the fact the Christians are able to successfully integrate into the labor market of the Jewish majority raises the possibility that the weak position of the Muslim salaried-employees does not stem from discrimination. It is likely that this weakness stems from the fact that the Arab labor force is not compatible with the Israeli labor market. It is therefore important to implement programs that will teach this sector of the population the skills they require for the labor market. This requires investment in areas such as education, vocational training, and so on. (3) The income earning ability of the Arab population in the self-employed sector is greater than its income earning ability in the salaried-employee sector. These findings indicate that in the short and medium term, steps should be taken that would enable the Muslims to be selfemployed by developing an industrial area for small businesses, setting up advisory centers, giving credit, and so forth. in the long term, the Muslims should be given help to acquire skills that will enable them to join the labor market. It is therefore necessary to continue with a study that will identify the areas that need to be reinforced to enable Muslim Arabs to be more successful at joining the labor market.

\section{References}

[1] Arrow, K. (1972). Some mathematical models of race discrimination in the labor market. in D. C. Health (ed.). Racial Discrimination in Economic Life. Lexington, Mass.

[2] Becker, G. S. (1993). Human capital: A theoretical and empirical Analysis, with Special reference to education. Chicago: University of Chicago Press

[3] Becker, K. (1971). The economics of discrimination. Chicago: University of Chicago Press.

[4] Central Bureau of Statistics, (2014). Local Authorities in Israel 2012. (Hebrew). http://www.cbs.gov.il/reader/?Mlval=cw_usr_view_SHTML\&ID=357

[5] Central Bureau of Statistics, (2013). Characterization and Classification of Local Authorities by the Socio Economic Level of the Population 2008. Publications No. 1530. (Hebrew). http://www.cbs.gov.il/reader

[6] Dahan, M. (2002). The rise of earning inequality. in A. Ben-Bassat (ed.). The Israeli Economy 1985 - 1998: From Government Intervention to Market Economics (pp. 648-651). Cambridge and London: MIT Press. (Hebrew).

[7] Darity, W. (1989). What left of the economic theory of discrimination?. in W. Darity (ed.). The Question of Discrimination: Racial Inequality in the U.S. Labor Market, Middletown: Conn. Wesleyan University Press. 
[8] Friedman F., \& Zussman, N. (2008). Labor quality in israel. Research Department, Bank of Israel. (Hebrew) http://www.boi.org.il/he/Pages/Default.aspx

[9] Haberfield, Y. (1990). Salary discrimination against women in israel: a conceptual framework, research methods, findings and trends. Human Resources and Labor Relations in Israel. Tel Aviv: Ramot. (Hebrew).

[10] Gharrah, R., \& Cohen, R. (2001). Poverty among israeli Aarabs and sources of inequality between Arabs and Jews. The Economic Quarterly, 48, 485-517.

[11] Hasson, S., \& Abu-Asbah K. (2004). Jews and Arabs in Israel. Floersheimar Studies, Jerusalem.

[12] Hasson,S., \& M. Karayanni. (2006). Barriers to equality: The Arabs in Israel. Floersheimar Studies, Jerusalem.

[13] Kleiman, E. (2001). Integrated or separated and may even be equal. The Economic Quarterly, 48, 648-651.

\section{Appendix: Example of ethnic discrimination}

Let us suppose that patients belonging to the majority group (Jews in the case of Israel) refuse to be treated by a doctor belonging to the minority group (an Arab in this case). The hospital is therefore forced to dismiss the doctor (or to employ him or her in an inferior position). in such a case, it could be claimed that the employment and income-earning disparity between Jews and Arabs stems from discrimination. The main ways that Jewish patients can distinguish that this is an Arab doctor is by his or her accent and the typical way in which they speak Hebrew, as well as their name (Arabs tend to have names that are different from those use by Jews). Given that both Muslim Arabs and Christian Arabs speak the same form of Arabic, and that they also have similar names, a Jewish patent cannot differentiate between them. This implies that if there is discrimination of this type against Muslim Arabs then it will also exist with regard to Christian Arabs. Consequently, the fact that the position of Christian Arabs is not inferior of that of Jews raises the possibility that the inferior status of Muslim Arabs does not stem from discrimination. 